\title{
Arbuscular mycorrhizal fungi and plant root exudates bio-communications in the rhizosphere
}

\author{
Monther Mohumad Tahat* and Kamaruzaman Sijam \\ Faculty of Agriculture, University Putra Malaysia 43400 UPM, Serdang, Selangor Darul Ehsan, Malaysia. \\ Accepted 26 September, 2012
}

\begin{abstract}
The pre-symbiosis of arbuscular mycorrhizal fungi (AMF) is induced by the production of specific plant root exudates. Mycorrhizal fungi symbiotic relationships have many benefits to the plants. These benefits include, improved plant growth and developments, and enhanced plant tolerance to several diseases. Over the pre-symbiotic phase, the root releases essential metabolites necessary for fungal growth and root colonization. Root exudates compounds were reported and identified by several researchers. Root exudates have sugar, amino acids, proteins, carbon, some lipophilic compounds, flavonoids, and other bio-molecules. These compounds were presented as a critical and fundamental signal in plant, fungal and microbe bio-communications in the soil. Root-microbe interactions are continuous occurrences in the biological active soil zone. Mycorrhizal fungi bio-interaction can be classified as positive (symbiotic) to the host or could be negative to the plant. Root exudates may act as messengers that communicate and initiate biological and physical interactions between soil organisms and roots. The current review will illustrate the role of root exudates in mycorrhizal fungi association, the major components of root exudates and more focus on the disease control by root exudates derived from plants mycorrhizosphere.
\end{abstract}

Key words: Mycorrhizal fungi, exudates, bio-communications, root, volatiles, non-volatiles.

\section{INTRODUCTION}

Arbuscular mycorrhizal fungi (AMF) are the major component of soil and land plant (Smith and Read, 2008). Arbuscular mycorrhizal symbiosis is the most widespread type of mycorrhizal association. It is estimated in about 250,000 of plants species, including many crops, vegetables, herbs and trees (Smith and Read., 1997; Koide and Dickie, 2002). More than $80 \%$ of the world's plant species are myorrhizas, ranging from flowering to non flowering plants, while only a few plant families do not form this association (Schenck, 1981; Schreiner and Bethlenfalvay, 1995; Harrier, 2001). Arbuscular mycorrhizal fungi are the key of soil microorganism components, which affect plant development and minerals uptake strongly (Tahat et al., 2008b). Plant roots influence the physical, chemical, and biological conditions of the soil in the rhizosphere (Gregory, 2006; Smith and Read, 2008).

Plant root exude a lot of valuable small molecular

\footnotetext{
*Corresponding author. E-mail: monthertahat@gmail.com.
}

compounds into the mycorrhizosphere (Bais et al., 2005). Root derived chemicals are the major signal between plant root and other soil microbes (Bais et al., 2005). Root exudates produce chemical compounds which may deter some organisms while attracting another. The typical example for that are the flavonoes chemical signals produced by soybean which attract mutualist Bradyribizobium japonicum and Phytophthora sojae pathogen (Morris et al., 1998). Plant fungal biocommunications and interactions are critical and essential tools for understanding the abundance and distribution of plant species (Bongard, 2012). The rhizosphere is the area for highly dynamic interactions and communications between plant roots system and the pathogens and other beneficial microbes (Hirsch et al., 2003).

The term, rhizosphere was induced initially by nutrients produced from host roots. The concept was expanded to mycorrhizosphere to describe the combination between micro-flora and mycorrhizae (Linderman, 1988). The combination of AMF and soil micro-flora in natural undisturbed agro-ecosystem would contribute to the 
effective growth and health of plants (Linderman, 2008). Chemicals secreted into the soil by roots are referred to as root exudates (Walker et al., 2003). Mycorrhizosphere composition included two sources, firstly; rhizosphere soil which is influenced by root exudates and secondly; mycorrhizosphere soil which is relative to mycorrhizae and impacted by exudates from the root tissues and hyphal fungi (Olsson et al., 1996; Andrade et al., 1997; Johansson et al., 2004).

Root exudates play a significant role in the mobilization of moderately soluble nutrients in the rhizosphere (Carvalhais et al., 2001). The microbial populations are an essential part of the rhizosphere and they affect soil rhizosphere by their several activities such as nutrient uptake, biological transformations and exudation (Filion et al., 1999). The presence of root exudates may influence chemical reaction mobility within the soil environment and subsequently affect biological activities, such as biogeochemical processes within the soil, which is fundamental for developing bioremediation technologies of inorganic and organic contaminants (Marschner, 1998). Therefore, the aims of current review were to focus on the mycorrhzial fungi and root exudates relationship in the mycorrhizosphere and to understand the ability of root exudates to control soil borne diseases.

\section{ARBUSCULAR MYCORRHIZAL FUNGI AND ROOT EXUDATES}

There are a number of researches on AMF and root exudates (Naghashi and Doudes, 2003; Vierheilig and Bago, 2005; Basi, 2003, 2005; Yu et al., 2003; Harrison, 2005). Root exudates play an important role in AMF establishment symbiosis (Vierheilig et al., 2003). The establishment of AMF symbiosis and infection structure can occur only in the presence of signals released by host roots (Smith and Read, 1997; Czarnota et al., 2003). AMF can find the presence of plant host through root exudates that is perceived as a signal from the plant (Naghashi and Douds, 2003). Plants colonized by AMF differ from non-mycorrhizal plant in rhizosphere microbial community and result in alterations in root respiration rate quality and quantity of the exudates (Marschner et al., 2001). AM colonization has been shown to change the amount and quality of host root exudates (Azaizeh et al., 1995) and the chemo tactic response of soil bacteria (Sood, 2003; Buee et al., 2000). Exudates from in vitro grown tomato roots colonized with Glomus intraradices were shown to modify the chemo tactic response of $P$. nicotianae zoospores (Lioussanne et al., 2008). Mycorrhizal fungi can alter root exudation quantitatively and qualitatively (Leyval and Berthelin, 1993). Specific relationships occur between mycorrhizosphere microbiota and mycorrhizal fungi, and there are several literatures attesting that mycorrhizal symbiosis is largely influenced by soil microbes (Bowen, 1980; Kosuta et al., 2003;
Garcia and Ocampon, 2002; De Oliveira and Garbaye, 1989).

\section{Exudates and mycorrhizae bio-action against soil- borne diseases}

Symbiotic interaction between plant root and microbes depends on secondary metabolites in the root exudates for beneficial association initiation and development (Vigo et al., 2000). The pathogenic interaction depends on understanding the chemical warfare mediated by plant secretion of phytoalexins, defense protein and other unknown chemical compounds (Flores et al., 1999; Bais et al., 2004, 2003). The protective effect of mycorrhizal symbioses against root pathogenic fungi has been tested by many researchers (Caron, 1989; St-Arnaud and Vujanovic, 2007; Oger et al., 2004). Disease decrease within plants colonized by mycorrhizal species is the result of the complex interactions between pathogens, AMF and plant (Harrier and Watson, 2004). Mycorrhizal symbiosis has been shown to lessen the damage caused by soil-borne pathogens (Azcon-Aguilar and Barea, 1996). Phytophthora parasitica proliferation was greatly minimized when tomato root were colonized by Glomus mosseae and $P$. parasitica compared with nonmycorrhizal tomato roots (Cordier et al., 1996).

Several biotic and a biotic factors are very important for the determination of efficiency of AMF as a disease control agent such as soil moisture, soil contents, host genotype, mycorrhizal level inoculums, inoculation time of mycorrhiza, mycorrhizal fungi species virulence, inoculums potential of pathogen and soil microflora (Singh et al., 2000). The increasing nutrient uptake resulted in more vigorous plants; thus, the plant itself may be more resistant or tolerant to pathogen attack (Linderman, 1994). Improvements in plant growth followed by root colonization by AMF occurs as a result of enhancement of the mineral nutrient status of plants (Akhtar and Siddiqui, 2008). Phosphorus tolerant AMF reduced nematode effect under high-P conditions; therefore, non-P-mediated mechanisms are involved, probably physiological changes in the roots (Sharma et al., 2007).

Root exudates from mycorrhizal strawberry plants suppressed the sporulation of $P$. fragariae in in vitro study (Norman and Hooker, 2000). Differential growth of Fusarium oxysporum $f$. sp chrysanthemi, Trichoderma harzianum, Clavibactor michiganesis and Pseudomonas chlororaphis was explained by substances released from G. intraradices under in vitro culture conditions (Filion et al., 1999). Grandmaison et al. (1993) suggested that phenolic compounds bound to cell wall could be indirectly responsible for the resistance of AMF roots to pathogenic fungi since they increased the resistance of cell wall to the action of digestive enzymes.

Phytoalexins toxic components are not detected during 
the first stages of AMF formation but can be detected in the later stages of symbiosis (Morandi, 1996). $P$. parasitica development decreased in G. mosseae and non G. mosseae parts of tomato mycorrhizal root systems in association with plant cell defense responses and accumulation of phenolics. Cortical cells containing G. mosseae are immune to the pathogen and exhibit a localized resistance response (Cordier et al., 1998). Exudates from fungal mycelium were also shown to impact germination of other pathogens and soil microbes (Steinkellner et al., 2008). Extracts from G. intraradices mycelium stimulated the growth of Ps. chlororaphis and $T$. harzianum, had no effect on $C$. michiganens and reduced conidial germination of $F$. oxysporum $f$. sp. chrysanthemi (Filion et al., 1999). The use of natural products for the control of fungal diseases in plants is considered an interesting alternative to synthetic fungicide due to their less negative impact on the environment (Brunelli, 1995).

Root exudates are considered as one of the mechanisms that explain the ability of AMF to suppress or increase the soil-borne diseases (Mukerji et al., 2002). Root exudates vary between different hosts, and the composition of the exudates changes in the same plant at different conditions (Marschner, 1995; Tahat et al., 2011). The current knowledge about the importance of exudates in AM fungus-host interactions was recently developed in in vitro culture technique and in situ compartmental systems. Although it is believed that root exudates play a major role in the infection and colonization of hosts by AMF, the actual role or mode of action of exudates was elucidated only recently (Nagahashi, 2000; Smith and Read, 2008).

The germination of $F$. oxysporum $f$. sp Lycopersici was inhibited in the presence of root exudates from the tomato plant (Scheffknecht et al., 2006). Root exudates can have direct defensive qualities. Pathogen-activated plant defenses can result in root secretion of antimicrobial compounds. It was shown that root-derived anti-microbial metabolites from Arabidopsis confer resistance to a variety of $P$. syringae pathovars (Bais et al., 2005). In another study, it was also predicted that transgenic plants that produce antimicrobial proteins can influence rhizosphere microbial communities (Glandorf et al., 1997). Sugars and amino acids in the root exudates stimulate the germination of chlamydospores and other fungi resting spores. The hyphal length of $G$. mosseae was greatly affected by the exudates of mycorrhizal tomato root exudates and mycorrhizal corn root exudates. The growth of Ralstonia solanacearum was suppressed due to $G$. mosseae spores germination (Tahat et al., 2010b).

The effect of parasitic nematode in the rhizosphere root exudates was studied (Foster, 1986; Griffiths, 1989; Horiuch et al., 2005). Root feeding nematode could participate in the interaction with root and soil ' $S$ ' microorganisms (Bais et al., 2006). Most information of microbe-nematode interaction in mycorrhizosphere and rhizosphere has been derived from rhizobi, mycorrhyza and plant pathogen researches (Khan, 1993). Horiuch et al. (2005) found that Caenorbabditis elegans may arrange interaction between plant roots and rhizobia in a positive way luminary to nodulation. In the same study, Horiuch et al. (2005) reported that $C$. elegan can transfer the Sinorbizobium meliloti (rhizobium species) to the root of Medicago truncatula in response to volatiles that released from plant root that attract nematode.

The hairy root exudates of sweet basil (Ocimum basilicum) cultures of elicited by fungal cell wall were extracted from $P$. cinnamoni. Basil roots were induced to exude rosmarinic acid (RA) by fungal in situ challenge by Pythium ultimum, and RA demonstrated strong antimicrobial activity against soil-borne microorganisms such as $P$. aeruginosa (Bais et al., 2002b). Hairy roots of Lithospermum erythrorhizon cell specifically produced naphthoquinones pigment upon elicitation, and other biological activity against soil-borne bacteria and fungi. The observed antimicrobial activity of RA and naphthoquinones suggest the importance of root exudates in defending the rhizosphere against pathogenic microorganisms (Brigham et al., 1999).

\section{Root exudates components}

Root exudates are divided into two compound classes; firstly, low-molecular weight (amino acids, sugar, phenolic and organic acid), and secondly, high-molecular weight exudates (protein and polysaccharides) (Marschner, 1995). The composition of root exudates can be complex and ranges from mucilage, root border cells, extracellular enzymes and sugars (complex and simple) (Shi et al., 2011; Jones et al., 2004), phenolics (Marschner, 1995; Tsai et al., 1991), amino acids and organic acids (OAs) (acetic, butyric, citric, fumaric, lactic, malic, propionic, succini) (Shi et al., 2011), carbon (Bodelier et al., 1997), phenylpropanoids, flavonoids and isoflavonoids Tsai and Phillips 1991; Winkel-Shirley, 2001; Buee et al., 2000; Peters et al.,1986, proteins (Glandorf et al., 1997), vitamins, (thiamine, nicotinic acid, biotin), nitrogenous macro-molecules such as nucleosides and purines to inorganic or gaseous molecules such as $\mathrm{HCO}_{3}^{-}, \mathrm{OH}^{-}, \mathrm{H}^{+}$, $\mathrm{CO}_{2}$ and $\mathrm{H}_{2}$ (Marschner, 1995; Uren and Reisennuer, 1988; Nagahashi and Jr-Douds 2003).

Enzymes (amylase, invertase, protease, phosphatase), organic substrates excreted into the rhizosphere, particularly amino acids, organic acids, proteins, carbohydrates and vitamins, promote microbial biosynthesis of ethylene (Arshad and Frankernberger, 1990; Dakora and Phillips, 2002). Root exudates are the highest source of allelochemical input into the soil environment and it is a source of many growth factors phytohormones (choline, biotin, inositol, and pyridoxine) (Su and Cheng, 2008). Root exudates are an 
important source of organic carbon to soil mycorrhizosphere (Foster, 1986). Different phytotoxins in root exudates were defined (Einhellig, 1995). The plant phytotoxins affect different plant aspects like photosynthesis, respiration, germination, root development shoot growth and cell mortality in target plant (Weir et al., 2004).

\section{Factors affecting exudates}

The nature and amount of chemical substances thus exuded are dependent on several factors such as soil type, soil microorganisms, nutrients availability, soil $\mathrm{pH}$ level, plant host species, plant age, temperature, organic, inorganic, light intercity and $\mathrm{O}_{2} / \mathrm{CO}_{2}$ level, but the most important factors are:

\section{Microorganisms}

Root exudates were found to increase microbial activities in the rhizosphere (Oger et al., 2004). In the rhizosphere, the roots must compete with the invading root systems of neighboring plant for water, space, nutrients and with soil-borne microorganisms, including fungi, bacteria, and insects feeding on an abundant source of organic material (Ryan and Delhaize, 2001; Burke et., 2002). Root exudates may act as messengers that initiate physical and biological interactions between roots and soil micro-organisms (Walker et al., 2003). Roots exudates regulate the soil microbial community in their immediate vicinity, through the exudation of a wide variety of compounds, encourage beneficial symbioses, change the chemical and physical properties of the soil, and inhibit the growth of competing plant species (Nardi et al., 2000; Sylvia et al., 2005). The exudates compounds can cause some nutrient elements to be relatively more available for uptake by plants. The exudation rate is increased by the presence of microbes in the rhizosphere (Gardner et al., 1983; Koo et al., 2005).

\section{Soil pH and fertilizers}

Root exudates compound solutions stimulated soil dehydrogenase activity, and the addition of OAs increased soil pH (Shi et al., 2011). Acidification of the rhizosphere is an important nutritional effect that organic acids have in root exudates (Dinkelaker et al., 1989). High concentrations of anions organic acid in root exudation will lade to $\mathrm{P}$ deficiency (Hoffland et al., 1989) and this lowers rhizosphere $\mathrm{pH}$, making $\mathrm{P}$ and $\mathrm{Mn}, \mathrm{Fe}$ and $\mathrm{Zn}$ to be more available in calcareous soils (Haynes, 1990; Jones and Darrah, 1994). The relationship between organic acid exudation and rhizosphere acidification is not that simple as the extrusion of $\mathrm{H}^{+}$. Acidification below pH 5.5 can cause some major macronutrients to become limiting because micronutrients such as $\mathrm{Mn}, \mathrm{Fe}$ and $\mathrm{Al}$ occur in high concentrations below pH (5.5) (Brady, 1990). Ammonium nutrition acidification does not result in increased phosphorus mobilization (Gahoonia et al., 1992). $\mathrm{H}^{+}$ extrusion occurs during $\mathrm{N}$ fixation by symbiotic legumes (Raven et al., 1990). This can lead to rhizosphere acidification and increased availability of limiting elements nutrient like P, Mo and Fe (Gahoonia, 1993; Gillespie and Pope, 1990). There are many documents of enhanced $\mathrm{H}_{2}{ }^{+}$extrusion under $\mathrm{P}$ deficiency and Fe deficiency, leading to acidification of localized areas around the root tips (Bienfait, 1988; Hoffland et al., 1989; Romheld and Marschner, 1986; Kania et al., 2003). Organic acids from root exudates can solubilize unavailable soil $\mathrm{Ca}, \mathrm{Fe}$ and Al phosphates. Rooibos tea (Aspalathus linearis L.) can actively modify their mycorhizosphere $\mathrm{pH}$ by extruding $\mathrm{OH}^{-}$and $\mathrm{HCO}_{3}{ }^{-}$to facilitate growth in low pH soils $(\mathrm{pH} 3$ to 5) (Dakora and Phillips, 2002). Extracellular enzymes release $P$ from organic compounds, and some types of molecules increase iron availability through chelation (Berg et al., 2002).

\section{Plant characteristics (species, age, nutrients, light)}

Different plant species inhabit variable microflora in the mycorrhizosphere region (Dakora and Phillips, 1996). The quantitative and qualitative differences are attributed to variations in the excretion products, rooting habits, and tissue composition (Mukerji et al., 2002). Plant age alters the rhizosphere microorganism and the stage of plant maturity controls the magnitude of rhizosphere effect and degree of response to specific microorganisms (Buée et al., 2009). Flowering is the most active period of plant metabolism and growth. The mycorrhizosphere microorganism increase in the highest number during this stage lead to increase exudates content (Walker et al., 2003; Tahat et al., 2008a). Some microbes were found to be more effective at the time of flowering than in the seedling or full maturity stage (Bais et al., 2006). The effect of light on the production of pectin and polygalacturonase (PG) in the root exudates of Trifolium alexandrinum inoculated with an efficient strain of Rhizobium trifolii was investigated. The pectin methyl esterase PME and PG increased with an increase in the duration of light to which plants were exposed (Chhonkar, 1978).

\section{CONCLUSION}

Mycorrhizal fungi associated with plant roots have existed for hundreds of millions of years. The role of mycorrhizal fungi in improving plant nutrition and their interactions 
with other soil biota have been investigated with reference to the host plant growth, but little is known about how these interactions affect soil structure. The combination of these organisms in natural, undisturbed ecosystems would seem to contribute to the successful growth and health of plants. Several factors influenced the production of root exudates such as plant type, age, light, soil microflora, soil fertilizer and soil $\mathrm{pH}$. This view has attempted to characterize qualitative changes in populations of rhizobacteria associated with plants with mycorrhizae in what is called the "mycorrhizosphere". Microbial populations in the mycorrhizosphere can change dynamically over time and are influenced by what microbes are present in the background soil or growth medium. The process of selective enrichment of specific functional groups of microbes from that medium is due to root and arbuscular mycorrhizal fungus, hyphal exudates.

\section{ACKNOWLEDGEMENT}

Special thanks to the University Putra Malaysia for supporting this work

\section{REFERENCES}

Akhtar MS, Siddiqui ZA (2008). Arbuscular mycorrhizal fungi as potential bioprotectants against plant pathogens: In Mycorrhizae: Sustainable Agriculture and Forestry. (Eds): M.S. Akhtar and ZA. Siddiqui, and Futai K pp: 61-97. Springer Netherlands.

Andrade G, Mihara KL, Linderman, RG, Bethlenfalvay GJ (1997). Bacteria from rhizosphere and hyphosphere soils of different arbuscular-mycorrhizal fungi. Plant Soil 19(2):71-79.

Arshad M, Frankernberger Jr (1990). Ethylene accumulation in soil in response to organic amendments. Soil Sci. Soc. Am. J. 54:10261031.

Azaizeh HA, Marschner H Romheld V, Wittenmayer L (1995). Effects of a vesicular-arbuscular mycorrhizal fungus and other soil microorganisms on growth, mineral nutrient acquisition and root exudation of soil-grown maize plants. Mycorrhiza 5:321-327.

Azcon-Aguilar C, Barea JM (1996). Arbuscular mycorrhizas and biological control of soilborne plant pathogens-an overview of the mechanisms involved. Mycorrhiza 6:457-464.

Bais HP, Walker HP, Schweizer Vivanco JM (2002a). Root specific elicitation and antimicrobial activity of rosmarinic acid in hairy root cultures of sweet basil (Ocimum basilicum L.). Plant Physiol. Biochem. 40:983-995.

Bais HP, Walker FR, Stermitz RA, Hufbauer VJM (2002b). Enantiomeric-dependent phytotoxic and antimicrobial activity of (+/-)catechin. A rhizosecreted racemic mixture from spotted knapweed. Plant Physiol. 128:1173-1179.

Bais HP, Vepachedu R, Gilroy S, Callaway RM, Vivanco JM (2003). Allelopathy and exotic plant invasion: from molecules and genes to species interactions. Science 301:1377-1380.

Bais HP, Park SW, Weir TL, Callaway RM, Vivanco JM (2004). How plants communicate using the underground information super high way. Trends Plant Sci. 9:26-32.

Bais HP, Prithiviraj B, Jha AK, Ausubel FM, Vivanco JM (2005). Mediation of pathogen resistance by exudation of antimicrobials from roots. Nature 434:217.

Bais HP, Weir TL, Perry GL, Gilroy S, Vivanco JM (2006). The role of root exudates in rhizosphere interactions with plants and other organisms. Annu. Rev. Plant Biol. 57:233-266.

Berg G, Roskot N, Steidle A, Eberl L, Zock A, Smalla K (2002). Plant- dependent genotypic and phenotypic diversity of antagonistic rhizobacteria isolated from different Verticillium host plants. Appl. Environ. Microbiol. 68:3328-3338.

Bienfait HF (1988). Mechanisms in Fe efficiency reactions of higher plants. J. Plant Nutr. 11:605-629.

Bodelier PL, Wijlhuizen CW, Blom PM, Laanbroek, HJ (1997). Effects of photo-period on growth of and denitrification by Pseudomonas chlororaphis in the root zone of Glyceria maxima, studied in a gnotobiotic microcosm. Plant Soil 190:91-103.

Bongard C (2012). A review of the influence of root-associating fungi and root exudates on the success of invasive plants. NeoBiota 14:2145, doi: 10.3897/neobiota. pp. 14-2927.

Bowen GD (1980). Misconceptions, concepts and approaches in rhizosphere biology. In: Ellwood, D.C., Hedger, J.N., Latham, M.J., Lynch, J.M., Slater, J.M. (Eds). Contempary Microbial Ecology. Academic, London, pp. 283-304.

Brady NC (1990). The nature and properties of soils. 10th edition. 621 pp. Macmillan Publishing Company.

Brigham LA, Michaels PJ, Flores HE (1999). Cell-specific production and antimicrobial activity of naphthoquinones in roots of Lithospermum erythrorhizon. Plant Physiol. 119:417-428.

Brunelli A (1995). I prodotti naturali nella lotta alle malattie fungine. La Difesa delle Piante, 18(2):57-69.

Buée M, De Boer W, Martin F, van Overbeek L, Jurkevitch E (2009). The rhizosphere zoo: An overview of plant-associated communities of microorganisms, including phages, bacteria, archaea, and fungi, and of some of their structuring factors. Plant Soil 321:189-212.

Buee M, Rossigno M Jauneaul A, Ranjeva R, Becard G (2000). The pre-symbiotic growth of arbuscular mycorrhizal fungi is induced by a branching factor partially purified from plant root exudates. The American Phyto-pathological Society, MPMI 13(6):693-698.

Burke DJ, Hamerlynck EP, Hahn D (2002). Interactions among plant species and microorganisms in salt march sediments. Appl. Environ. Microbiol. 68:1157-1164.

Caron M (1989). Potential use of mycorrhizae in control of soil-borne diseases. Can. J. Plant Pathol. 11:177-179.

Carvalhais LC, Dennis PG, Fedoseyenko D, Hajirezaei MR, Borriss R, von Wiren N ( 2011). Root exudation of sugars, amino acids, and organic acids by maize as affected by nitrogen, phosphorus, potassium, and iron deficiency J. Plant Nutr. Soil Sci. 174:3-11.

Chhonkar PK (1978). Influence of light on pectic enzymes in root exudates of Trifolium alexandrinum inoculated with Rhizobium trifolii. Zentralbl Bakteriol Naturwiss. 1978; 133(1):50-3. Co., New York, NY.

Cordier C, Pozo MJ, Barea JM, Gianinazzi S, Gianinazzi-Pearson V (1998). Cell defense responses associated with localized and systemic resistance to Phytophthora parasitica induced in tomato by an arbuscular mycorrhizal fungus. MPMI. 11:1017-1028.

Cordier C, Gianinazzi S, Gianinnazzi-Pearson V (1996). Colonization patterns of root tissues by Phytophthora nicotianae var.parasitica related to reduced disease in mycorrhizal tomato. Plant Soil 185:223232.

Czarnota MA, Rimando AM, Weston LA (2003). Evaluation of root exudates of seven sorghum accessions. J. Chem. Ecol. 29:20732083.

Dakora FD Phillips DA (1996). Diverse functions of iso- flavonoids in legumes transcend anti-microbial definitions of phytoalexins. Physiol. Mol. Plant Pathol. 49:1-20.

Dakora FD, Phillips D ( 2002). Root exudates as mediators of mineral acquisition in low-nutrient environments. Plant Soil. 245:35-47.

De Oliveira VL, Garbaye J (1989). SymbiosisLes microorganisms aids the establishment of ectomycorrhizal symbiosis. Eur. J. Pathol. 19:54-64.

Dinkelaker B, Romheld V, Marschner H (1989). Citric acid excretion and precipitation of calcium citrate in the rhizosphere of white lupin (Lupinus albus L). Plant Cell Physiol. 12:285-292.

Einhellig F (1995). Mechanisms of action of allelochemicals in allelopathy. In Allelopathy: Organisms, Processes, and Applications, ed. Inderjit, KMM Dakshini, FA Einhellig, pp. 96. Washington, DC: Am. Chem. Soc.

Filion M, St-Arnaud M, Fortin JA (1999). Direct interaction between the arbuscular mycorrhizal fungus Glomus intraradices and different rhizosphere microorganisms. New Phytol. 141:525-533. 
Flores HE, Vivanco JM, Loyola-Vargas VM (1999). Radical biochemistry: the biology of root-specific metabolism. Trends Plant Sci. 4:220-26.

Foster RC (1986). The ultrastructure of the rhizoplane and rhizosphere. Annu. Rev. Phytopathol. 24:211-34.

Gahoonia TS, Claassen N, Jungk, A (1992). Mobilization of phosphate in different soils by ryegrass supplied with ammonium or nitrate., Plant Soil 140:241-248.

Gahoonia TS (1993). Influence of root-induced pH on the solubility of soil aluminium in the rhizosphere., Plant Soil 149:289-291.

Garcia-Garrido JM, Ocampo JA (2002). Regulation of the plant defense response in arbuscular mycorrhizal symbiosis. J. Exp. Bot. 53:137786.

Gardner WK, Barber DA, Parbery DG (1983). The acquisition of phosphorus by Lupinus albus L. III. The probabale mechanism by which phosphorus movement in the soil/root interface is enhanced., Plant Soil 70:107-124.

Gillespie AR, Pope PE (1990). Rhizosphere acidification in- creases phosphorus recovery of Black locust: I. Induced acidi- fication and soil response., Soil Sci. Soc. Am. J. 54:533-537.

Glandorf DC, Bakker PA, Van Loon LC (1997). Influence of the production of antibacterial and antifungal proteins by transgenic plants on the saprophytic soil microflora. Acta Bot Neerl. 46:85-104.

Grandmaison J, Olah GM, Van Calsteren MR, Furlan V (1993). Characterization and localization of plant phenolics likely involved in the pathogen resistance Mycorrhiza. 3(4):155-164.

Gregory PJ (2006). Roots, rhizosphere, and soil: the route to a better understanding of soil science? Eur. J. Soil Sci. 57:2-12.

Griffiths BS (1989). The role of bacterial feeding nematodes and protozoa in rhizosphere nutrient cycling. Asp. Appl. Biol. 22:141-45.

Harrier AL (2001). The arbuscular mycorrhizal symbiosis: A-molecular review of the fungal dimension. J. Exp. Bot. 52: 469-478.

Harrier LA, Watson CA (2004). The potential role of arbuscular mycorrhizal (AM) fungi in the bio-protection of plants against soilborne pathogens in organic and/or other sustainable farming systems. Pest Manag. Sci. 60(2):149-157.

Harrison MJ (2005). Signaling in the arbuscular mycorrhizal symbiosis. Annu. Rev. Microbiol. 59:19-42.

Haynes RJ (1990). Active ion uptake and maintenance of cation- anion balance: A critical examination of their role in regulating rhizosphere pH. Plant Soil. 126:247-264.

Hirsch AM, Bauer WD, Bird DM, Cullimore J, Tyler B, Yoder JI (2003). Molecular signals and receptors: controlling rhizosphere interactions between plants and other organisms. Ecology 84:858-868.

Hoffland E, Findenegg GR, Nelemans JA (1989). Solubilization of rock phosphate by rape. II Local root exudation of organic acids as a response to P-starvation. Plant Soil. 113:161-165.

Horiuchi JI, Prithiviraj B, Bais HP, Kimball BA, Vivanco JM (2005). Soil nematodes mediate positive interactions between legume plants and rhizobium bacteria. Planta 15:1-10.

Johansson JF, Paul LR, Finlay RD (2004). Microbial interactions in the mycorrhizosphere and their significance for sustainable agriculture. FEMS Microbiol. Ecol. 48(1):1-13.

Jones DL Darrah PR (1994). Role of root derived organic acids in the mobilization of nutrients from the rhizosphere. Plant Soil. 166:247257.

Kania A, Neumann G, Martinoia Langlade EN (2003). Phosphorus deficiency-induced modifications in citrate catabolism and in cytosolic $\mathrm{pH}$ as related to citrate exudation in cluster roots of white lupin. Plant Soil 248:117-127.

Koide RT, Dickie IA (2002). Effects of mycorrhizal fungi on plant populations. Plant Soil 244:307-317.

Koo B, Adriano DC, Bolan S, Barton CD (2005). Root exudates and microorganisms. p. 421-428. In Encyclopedia of Soils in the Environment, edited by D. Hillel. Elsevier Academic Press.

Amsterdam, The Netherlands

Kosuta S, Chabaud M, Lougnon G, Gough C, Denarie J, Barker DG, Becard $G$ (2003). A diffusible factor from arbuscular mycorrhizal fungi induces symbiosis-specific MtENOD11 expression in roots of Medicago truncatula. Plant Physiol. 131:952-962.

Leyval C, Berthelin J (1993). Rhizodeposition and net release of soluble organic compounds of pine and beech seedlings inoculated with rhizobacteria and ectomycorrhizal fungi. Biol. Fert. Soils 15:259-267.

Linderman RG (1988). Mycorrhizal interactions with the rhizosphere microflora: The mycorrhizosphere effect. Phytopathology 78:366-371.

Linderman RG (1994). Role of VAM fungi in biocontrol . In: Pfleger F. L. and Linderman R. G. Mycorrhizae and Plant Health . pp. 1-27. American Phytological Society, St. Paul.M.N.

Linderman RG (2008). The mycorrhizosphere phenomenon. pp 341-355 In: Mycorrhiza Works. Feldman F, Kapulnik Y, Barr J (Eds.), Deutsche Phytomedizinische Gesellschaft, Braunschweig, Germany.

Lioussanne L, Jolicoeur M, St-Arnaud M (2008). Mycorrhizal colonization with Glomus intraradices and development stage of transformed tomato roots significantly modify the chemo tactic response of zoospores of the pathogen Phytophthora nicotianae. Soil. Biol. Biochem. 40(22):1722-1724.

Marschner H (1995). Mineral Nutrition of Higher Plants. 2nd Edn. Academic Press, London. $889 \mathrm{pp}$.

Marschner, H, 1998. Role of root growth, arbuscular mycorrhiza, and root exudates for the efficiency in nutrient acquisition. Field Crops Res. 56:203-207.

Marschner P, Crowley D, Lieberei R (2001). Arbuscular mycorrhizal infection changes bacterial 16s DNA community composition in the rhizosphere of maize. Mycorrhiza 11:297-302.

Morandi D (1996). Occurrence of phytoalexins and phenolic compounds in endomycorrhizal interaction, and their potential role in biology control. Plant Soil 185:241-251.

Morris PF, Bone E, Tyler BM (1998). Chemotropic and contact responses of Phytophthora sojae hyphae to soybean isoflavonoids and artificial substrates. Plant Physiol. 117:1171-1178.

Mukerji KG, Manoharachary C, Chamola B (2002). Techniques in mycorrhizal studies. Kluwer Academic Publishers. LondonNetherlands, pp. 285-296.

Nagahashi G, Jr-Douds DD (2003). Action spectrum for the induction of hyphal branches of an arbuscular mycorrhizal fungus: exposure sites versus branching sites. Mycol. Res. 107:1075-1082.

Nagahashi G, (2000). In vitro and in situ techniques to examination the role of roots and root exudates during AM fungus-host interactions. In: Kapulink, Y and. Douds. Jr., D. Arbuscular Mycorrhizas: Physiology and Function: eds, Kluwer Academic Publishers. Netherlands., pp. 278-300.

Nardi S, Concheri G, Pizzeghello D, Sturaro A, Rella R, Parvoli G (2000). Soil organic matter mobilization by root exudates. Chemosphere 5:653-658.

Norman JR, Hooker JE (2000). Sporulation of Phytophthora fragariae shows greater stimulation by exudates of non-mycorrhizal than by mycorrhizal strawberry roots. Mycol. Res. 104:1069-1073.

Oger PM, Mansouri H, Nesme X, Dessaux Y (2004). Engineering root exudation of Lotus toward the production of two novel carbon compounds leads to the selection of distinct microbial populations in the rhizosphere. Microb. Ecol. 47:96-103.

Olsson PA, Baath E, Jakobsen I, Soderstrom B (1996). Soil bacteria respond to presence of roots but not to mycelium of arbuscular mycorrhizal fungi. Soil Biol. Biochem. 28:463-470.

Peters NK, Frost JW, Long SR (1986). A plant flavone, luteolin, induces expression of Rhizobium meliloti nodulation genes. Science 233:97780.

Raven JA, Franco, AA De Jesus EL Jacob-Neto J (1990). H+extrusion and organic-acid synthesis in $\mathrm{N}$-fixing symbioses involving vascular plants. New Phytol. 114, 369-389.

Romheld V, Marschner H (1986). Mobilization of iron in rhizo- sphere of different plant species. In Advances in Plant Nutrition, Volume 2. Eds. PBH Tinker and A Laüchli. pp. 155-204.

Ryan PR Delhaize E (2001). Function and mechanism of organic anion exudation from plant roots. Annu. Rev. Plant Physiol. Mol. Biol. 52:527-560.

Scheffknecht S, Mammerler R, Steinkellner S, Vierheilig H (2006). Root exudates of mycorrhizal tomato plants exhibit a different effect on microconidia germination of Fusarium oxysporum f. sp.lycopesici than root exudates from nonmycorrhizal tomato plants. Mycorrhiza 16(5):365-370.

Schenck NC (1981). Can mycorrhizae control root disease?. Plant Dis. 65:230-234.

Schreiner RP, Bethlenfalvay GJ (1995). Mycorrhizal interactions in 
sustainable agriculture. Crit. Rev. Biotechnol. 15:271-285.

Sharma MP, Gaur A, Mukerji KG (2007). Arbuscular mycorrhiza mediated plant pathogen interactions and the mechanisms involved. In: Sharma MP, Gaur A, Mukerji. KG Biological Control of Plant Diseases. pp. 47-63. Haworth Press.

Shi S, Richardson AE, O'Callaghan M., DeAngelis M, Jone EE (2011). Effectuates of selected root exudates components on soil bacterial communities. FEMS Microbiol. Ecol. 77 600-610.

Singh R, Adholega A, Mukerji KG( 2000). Mycorrhiza in control of soil borne pathogens. In: Mukerji KG, Chamola BP, Singh,J (eds)., Mycorrhizal Biology, Kluwer Academic/Plenum Publishers, New York, USA, pp. 173-196.

Smith SE, Read. DJ (1997). Mycorrhizal symbiosis. $2^{\text {nd }}$ ed. Academic Press, London.

Smith SE, Read DJ (2008). Mineral nutrition, toxic element accumulation and water relations of arbuscular mycorrhizal plants. In: Smith, S. E and Read. D. J. Mycorrhizal Symbiosis. $3^{\text {rd }}$. pp. 145-18. Academic Press, London.

Sood SG (2003). Chemotactic response of plant-growth-promoting bacteria towards roots of vesicular-arbuscular mycorrhizal tomato plants. FEMS Microbiol. Ecol. 45:219-227.

St-Arnaud M, Vujanovic V(2007). Effect of the arbuscular mycorrhizal symbiosis on plant diseases and pests. In: Hamel C, Plenchette C (eds) Mycorrhizae in crop production. Haworth Press, Binghampton , New York, pp. 67-122.

Steinkellner S, Mammerler R, Vierheilig H (2008). Effects of membrane filtering of tomato root exudates on conidial germination of Fusarium oxysporum f. sp. lycopersici. J. Phytopathol. 156:489-492.

Su L, Cheng $Z$ (2008). Allium sativum extract as a biopesticide affecting pepper blight. Int. J. Vegetable Sci. 15(1):13-23.

Sylvia DF, Hartel JP, Zuberer D (2005). Principles and applications of soil microbiology. Pearson Education Inc. New Jersey.

Tahat MM, Radziah O, Kamaruzaman S, Kadir J, Masdek NH (2008a). Role of plant host in determining differential responses to Ralstonia solanacearum and Glomus mosseae. Plant Pathol. J. 7:140-147.

Tahat MM, Radziah O, Kamaruzaman S, Kadir J, Masdek NH (2008b).Response of (Lycopersicum esculentum Mill.) to different arbuscular mycorrhizal fungi species. Asian J. Plant Sci. 7:479-484.

Tahat MM, Sijam K, Othman R (2010b). The role of tomato and corn root exudates on Glomus mosseae spores germination and Ralstonia solanacearum growth in vitro. Int. J. Plant Pathol. 1:1-12.
Tahat MM, Sijam K, Othman R (2011). Bio-compartmental in vitro system for Glomus mosseae and Ralstonia solanacraum interaction. Int. J. Bot. 7: 295-299.

Tsai SM, Phillips DA (1991). Flavonoids releasaed naturally from alfalfa promote development of symbiotic Glomus spores in vitro. Appl. Environ. Microbiol. 57:1485-1488.

Uren NC, Reisenauer HM (1988). The role of root exudates in nutrient acquisition. Adv. Plant Nutr. 3:79-114.

Vierheilig H, Lerat S, Piche Y (2003). Systemic inhibition of arbuscular mycorrhiza development by root exudates of cucumber plants colonized by Glomus mosseae. Mycorrhiza 13:167-170.

Vierheilig H, Bago B (2005) Host and non-host impact on the physiology of the AM symbiosis. In: Declerck S, Strullu DG, Fortin JA (eds) In vitro culture of mycorrhizas. Springer, Heidelberg, pp. 139-158.

Vigo C, Norman JR, Hooker JE (2000). Bio-control of the pathogen Phytophthora parasitica by arbuscular mycorrhizal fungi is a consequence of effects on infection loci. Plant Pathol. 49:509-514.

Walker TS, Bais HP, Grotewold E, Vivanco JM (2003). Root exudation and rhizosphere biology. Plant Physiol. 132:44-51.

Weir TL, Park SW, Vivanco JM (2004). Biochemical and physiological mechanisms mediated by allelochemicals. Curr. Opin. Plant Biol. 7:472-479.

Winkel-Shirley B (2001). Flavonoid biosynthesis: a colorful model for genetics, biochemistry, cell biology and biotechnology. Plant Physiol. 126:485-493.

Yu JQ, Ye SF, Zhang MF, Hu WH (2003). Effects of root exudates and aqueous root extracts of cucumber (Cucumis sativus) and allelochemicals, on photosynthesis and antioxidant enzymes in cucumber. Biochem. Syst. Ecol. 31:129-39. 